Research Article

\title{
Study of anti-inflammatory effect of simvastatin in rats
}

\author{
Ranga Satya Venkatesh ${ }^{1} *$, Lakshmi Deepika Patchva $^{2}$, Singamma Muppa $^{2}$
}

\begin{abstract}
${ }^{1}$ Department of Pharmacology, Drug store officer, Central Drug store, Andhra Pradesh, India, ${ }^{2}$ Department of Pharmacology, Dr. Pinnamaneni Siddhartha Institute of Medical Sciences and Research Foundation, chinnaoutpalli, Andhra Pradesh, India,
\end{abstract}

Received: 26 May 2016

Revised: 04 July 2016

Accepted: 08 July 2016

\section{* Correspondence to: \\ Dr. Ranga Satya Venkatesh, Email: drrsvenkatesh25@ gamil.com}

Copyright: (C) the author(s), publisher and licensee Medip Academy. This is an openaccess article distributed under the terms of the Creative Commons Attribution NonCommercial License, which permits unrestricted noncommercial use, distribution, and reproduction in any medium, provided the original work is properly cited.

\begin{abstract}
Background: Inflammation is a complex reaction in tissues that consists mainly of response of blood vessels and leukocytes. Simvastatin is a hypolipedemic drug belonging to the class of statins. Statins are competitive inhibitors of 3 hydroxy-3-methylglutaryl-coenzyme A (HMG-CoA) reductase, the rate limiting enzyme in cholesterol synthesis, are widely prescribed for the treatment of hyperlipedemia. This study was conducted to evaluate the anti-inflammatory activity of simvastatin in albino rats using digital plethysmometer.

Methods: Male wistar albino rats weighing between 200-250 gm were selected for the study and rats were randomly divided into groups (control, standard, and test). The anti-inflammatory activity was evaluated by using carrageenan induced paw edema volume by using digital plethysmometer. Control group rats were administered $0.2 \mathrm{ml}$ of normal saline, whereas, test group rats were administered simvastatin $40 \mathrm{mg}$ and standard group diclofenac $50 \mathrm{mg}$ as single dose half an hour before injecting $0.1 \mathrm{ml}$ of $1 \%$ carrageenan to the sub-plantar region of hind paw of rat. The paw edema of each rat was measured at 0 hour and after 3 hours.

Results: At a dose of $40 \mathrm{mg}$ Simvastatin showed anti-inflammatory effect which is statically highly significant.

Conclusions: However, the above preclinical experiments only give us an idea about the anti-inflammatory activity, but large scale clinical trials are necessary for final assessment.
\end{abstract}

Keywords: Simvastatin, Diclofenac sodium, Normal saline, Carrageenan, Plethysmometer

\section{INTRODUCTION}

Inflammation is a dynamic process by which living tissue reacts to injury, particularly vascular and connective tissue injury. ${ }^{1}$ It is a complex reaction in tissues that consists mainly response of blood vessels and leukocytes. The word inflammation is taken from the Latin word "inflammare" meaning burning. It is defined as; "a process which follows sub lethal injury to tissue and ends with complete healing" as proposed by Ebert. ${ }^{2}$

Inflammation has multifactorial causes. Almost anything that injures living tissue can cause inflammation. ${ }^{3}$ The vascular and cellular reactions of inflammation are triggered by soluble factors that are produced by various cells or derived from plasma proteins and generated or activated in response to the inflammatory stimulus. ${ }^{1}$ Mediators of inflammation are prostaglandins, leukotrienes, histamine, bradykinin, cytokines growth factors; lysosomal contents of neutrophils, reactive oxygen species etc.

Simvastatin is a hypolipedemic drug belonging to the class of statins. ${ }^{4}$ It is a lipid-lowering agent, and is derived synthetically from lovastatin (formerly known as mevinclin) which was isolated from Aspergillus terreus. 
Simvastin is chemically modified derivative of lovastatin. ${ }^{5}$ It reduces very low density lipoprotein (VLDL), triglycerides (TG) and increases high density lipoprotein cholesterol (HDL-C). ${ }^{6}$

Statins exert beneficial effects beyond cholesterol reduction. They are improvement in endothelial function, decreasing vascular inflammation, inhibiting smoothmuscle proliferation and immunomodulation. In the present study, anti-inflammatory effect of simvastatin was evaluated and it was compared with diclofenac sodium by using digital plethysmometer.

\section{METHODS}

The animals used for the study were male albino rats (200-250 g). Animals are housed at central animal house of Dr. Pinnamenani Siddhartha Institute of Medical Sciences and Research foundation which is maintained under standard conditions. The rats are divided into 3 groups, and each group contains 6 rats. A mark is made at the ankle joint (tibio-tarsal joint) of each rat. Initial paw edema of each rat was measured before giving drug by using digital plethysmometer (0 hour reading). And paw edema of each rat was measured at 3 hours after administration of drug.

\section{Chemical}

Carrageenan, diclofenac sodium, simvastatin, double distilled water, normal saline, DMSO.

\section{Equipment}

Digital plethysmometer, insulin syringes, tuberculin syringes, measuring jar, glass beakers, animal weighing balance, animal cages, cotton.

\section{Carrageenan induced paw edema model}

To study the acute and sub-acute phases of inflammation in rats. Carrageenan is a widely used irritant or inflammogen or a phlogistic agent. Chemically, it is a sulphated polysaccharide obtained from sea weed (rhodophyceae). ${ }^{7}$ The experimental tissue injury caused by this irritant initiates a cascade of inflammatory events leading to formation of exudates. The inflammation induced by it is biphasic in nature. The first phase is attributed to the release of histamine, 5-hydroxy tryptamine (serotonin) and kinin while the second phase is related to the release of prostaglandins. The wellrecognized method of winter et al, 1962 is followed. ${ }^{8} 1 \%$ w/v suspension of carrageenan was prepared freshly in normal saline and injected into sub planter region of left hind paw (usually $0.1 \mathrm{ml}$ in rats). In control groups animal $0.2 \mathrm{ml}$ normal saline, standard group $50 \mathrm{mg}$ of diclofenac sodium and in test group $40 \mathrm{mg}$ simvastatin were injected intraperitonally half an hour before injecting $0.1 \mathrm{ml}$ of $1 \%$ freshly prepared carrageenan to the sub-plantar region of left hind paw and the paw edema of each rat is measured after 3 hours.

Difference in rat paw volume and \% reduction in paw edema was calculated using the following formula:

$\%$ Reduction in edema $=[($ Mean edema in control group Mean edema in drug treated group)/Mean edema in control group) $] \times 100$.

The readings were recorded by using a digital plethysmometer. Results are tabulated and "unpaired ttest" is used to find out the statistical difference in between the standard and test group animals.

\section{RESULTS}

Table 1: Volume of paw edema in $(\mathrm{ml})$ in three groups at 0 and 3 hours.

\begin{tabular}{|lllll|}
\hline Group & Drug & Dose & $\begin{array}{l}\text { Paw edema in ml } \\
\text { 0 hours } \\
\text { (mean } \pm \text { SD) }\end{array}$ & $\begin{array}{l}\text { 3 hours } \\
\text { (mean } \pm \text { SD) }\end{array}$ \\
\hline I & $\begin{array}{l}\text { Normal } \\
\text { saline } \\
\text { (control) }\end{array}$ & $0.2 \mathrm{ml}$ & $1.43 \pm 0.069$ & $2.23 \pm 0.155$ \\
\hline II & $\begin{array}{l}\text { Simvastat } \\
\text { in (test) }\end{array}$ & $40 \mathrm{mg}$ & $1.23 \pm 0.017$ & $1.27 \pm 0.018$ \\
\hline III & $\begin{array}{l}\text { Diclofenac } \\
\text { (standard) }\end{array}$ & $50 \mathrm{mg}$ & $1.42 \pm 0.083$ & $1.75 \pm 0.097$ \\
\hline
\end{tabular}

In the given table statistical tools have not been applied. I have used the un-paired student's t-test for evaluation of the results. After comparing the results there is a difference in the rat paw volume in test versus control and standard versus control. Simvastatin shows significant reduction in rat paw edema (Figure 1).

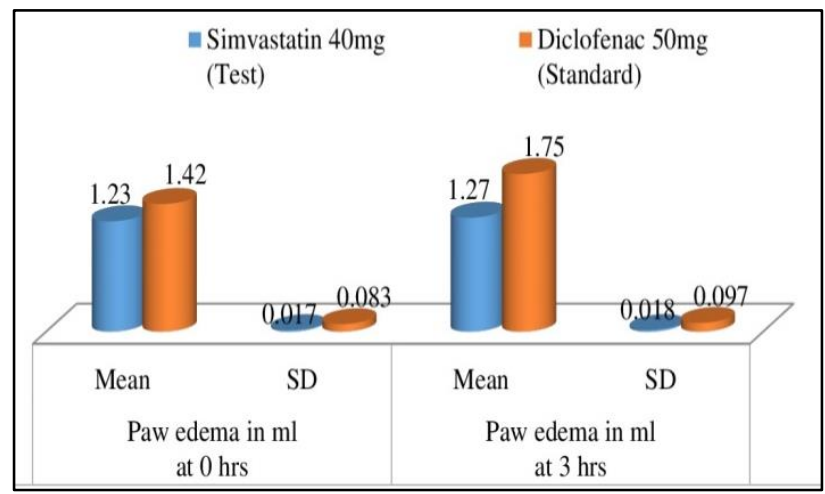

Figure 1: Comparison of paw edema in simvastatin group and diclofenac group at $\mathbf{0}$ and 3.

\section{Results show}

- $\quad$ Control group with $0.2 \mathrm{ml}$ of normal saline there was no decrease in rat paw edema 
- In standard group 50mg of Diclofenac showed significant inhibition of rat paw edema compared to normal saline

- In test group 40mg of Simvastatin showed significant inhibition of rat paw edema compared to standard Diclofenac.

Table 2: Comparison between simvastatin $40 \mathrm{mg}$ and diclofenac $50 \mathrm{mg}$ after 0 and 3 hours.

\begin{tabular}{|c|c|c|c|c|}
\hline \multirow{2}{*}{\multicolumn{2}{|c|}{ Group Drug }} & \multirow[b]{2}{*}{ Dose } & \multicolumn{2}{|c|}{ Paw edema in $\mathrm{ml}$} \\
\hline & & & $\begin{array}{l}\text { 0 hours } \\
(\text { mean } \pm \text { SD })\end{array}$ & $\begin{array}{l}3 \text { hours } \\
(\text { mean } \pm \text { SD }\end{array}$ \\
\hline I & $\begin{array}{l}\text { Simvastatin } \\
\text { (test) }\end{array}$ & $40 \mathrm{mg}$ & $1.23 \pm 0.017$ & $1.27 \pm 0.018$ \\
\hline II & $\begin{array}{l}\text { Diclofenac } \\
\text { (standard) }\end{array}$ & $50 \mathrm{mg}$ & $1.42 \pm 0.083$ & $1.75 \pm 0.097$ \\
\hline \multicolumn{2}{|c|}{$\begin{array}{l}\text { Un-paired t-test } \\
\text { t-statistic }\end{array}$} & & 5.45 & 11.84 \\
\hline \multicolumn{2}{|c|}{ df } & & 10 & 10 \\
\hline \multicolumn{2}{|c|}{$\mathrm{P}$-value } & & 0.001 & 0.0001 \\
\hline \multicolumn{2}{|c|}{ Inference } & & $\begin{array}{l}\text { Highly } \\
\text { significant }\end{array}$ & $\begin{array}{l}\text { Highly } \\
\text { significant }\end{array}$ \\
\hline
\end{tabular}

When the two drugs simvastatin $40 \mathrm{mg}$ and diclofenac 50 mg were compared and the results are evaluated. Simvastatin was found to have anti-inflammatory activity which was highly significant $(\mathrm{p}<0.01)$.

\section{DISCUSSION}

This study comprises HMG-COA reductase inhibitor Simvastatin tested and compared for its anti-inflammatory activity with a standard drug - diclofenac (non-selective COX inhibitor) by one of the acute method i.e., rat paw edema method. The current study demonstrates significant anti-inflammatory activity, by reduction in carrageenan induced paw edema method. The percentages of rat paw inhibition of standard and test drug at 0 and 3 hours are $0.70 \%$ and $21.52 \%$ and $13.99 \%$ and $43.05 \%$ respectively (Figure 2).

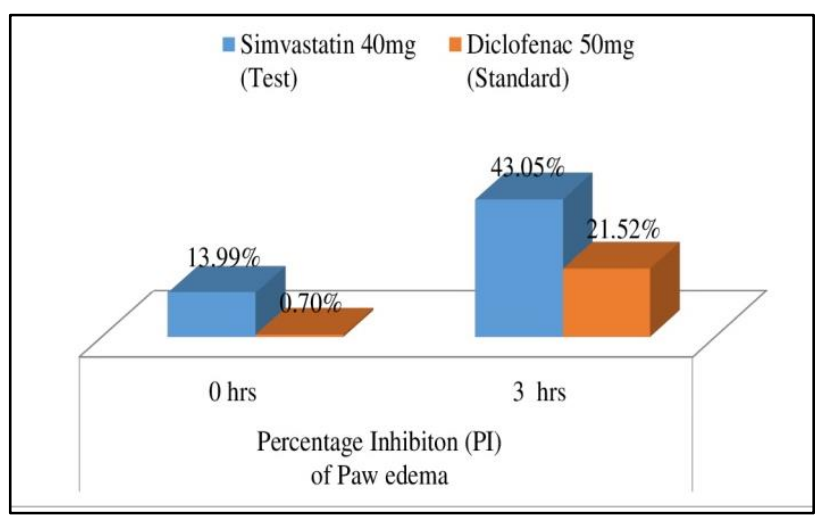

Figure 2: Comparison of percentage inhibition of simvastatin group and diclofenac group at 0 and 3 hours.
The possible mechanism of anti-inflammatory activity of simvastatin is probably related to inhibition of the production pro-inflammatory mediators. It is difficult to define in vivo the specific molecular mechanism by which statins affect the cell migration, because of complexity of the cholesterol synthesis. Statins interrupt the proinflammatory signalling by down-regulation of Rhorelated protein activation. Simvastatin requires peroxisome proliferator-activated receptor (PPAR) $\alpha$ expression to exert its anti-inflammatory effects in in-vivo models of acute local inflammation and in-vitro in macrophages and neutrophils.

\section{CONCLUSION}

This study was carried out to evaluate the antiinflammatory property of Simvastatin on rat hind paw edema using digital plethysmometer. At a dose of $40 \mathrm{mg}$ Simvastatin showed anti-inflammatory effect which is statically highly significant. However, the above preclinical experiments only give us an idea about the anti-inflammatory activity, but large scale clinical trials are necessary for final assessment.

\section{ACKNOWLEDGEMENTS}

Authors are very grateful to Dr. M. Singamma, Professor and HOD, Dept. of Pharmacology, Dr. PSIMS and RF for her valuable guidance for this study.

\section{Funding: No funding sources}

Conflict of interest: None declared

Ethical approval: The study was approved by the Institutional Ethics Committee, Dr. PSIMS and RF

\section{REFERENCES}

1. Kumar V, Abbas AK, Nelson F, Richard NM. Acute and chronic inflammation. Robbins basic pathology, $8^{\text {th }}$ edition; WB Saunders Co; 2007:31-58.

2. Goodman and Gillman, Anti-inflammatory, Antipyretic and Analgesic agents; Pharmacotherapy of Gout, chapter 34, The Pharmacological basis of Therapeutics, $12^{\text {th }}$ edition, The Pharmacological basis of therapeutics, $12^{\text {th }}$ edition, The Mac Graw Hill companies inc; 2011:986-987.

3. Tripathi KD. Hypolipaedimic drugs and plasma expanders, Chapter-45. Essential of Medical Pharmacology, $7^{\text {th }}$ edition. Jaypee brother publishers; 2013:638.

4. Liao JK, Laufs U. Pleiotropic effects of statins. Annu Rev Pharmacol Toxicol. 2005;45:89-118.

5. Evans M, Roberts A, Davies S, Rees A. Medical lipid-regulating therapy: current evidence, ongoing trials and future developments. Drugs. 2004;64:118196.

6. Srivastava K. Drugs for dyslipideamia, section 5, a complete textbook for medical pharmacology volume $1,1^{\text {st }}$ edition, Avichal Publishing company; 2012:327. 
7. Anderson WAD. Inflammation and healing. pathology, $9^{\text {th }}$ Edition, C.V. Mosby co. 1990;1:67.

8. Di Rosa M, Sorrenttino L. Biological properties of carrageenan. J Pharma Pharmacol. 1972;89:102.
9. Gosh MN. Experimental pharmacology. $5^{\text {th }}$ edition. Hilton and company. Gosh S.K publisher; 2007:120123.

Cite this article as: Venkatesh RS, Patchva LD, Muppa S. Study of anti-inflammatory effect of simvastatin in rats. Int J Basic Clin Pharmacol 2016;5:1520-3 